\title{
Role of trichomes on leaves and pods for imparting resistance in chickpea [Cicer arientinum (L.)] genotypes against Helicoverpa armigera (Hübner)
}

\author{
Husandeep Singh Brar ${ }^{1^{*}}$ and Ravinder Singh ${ }^{2}$ \\ ${ }^{1}$ Department of Entomology, Punjab Agricultural University, Ludhiana-141004 (Punjab), INDIA \\ ${ }^{2}$ Department of Plant Breeding and Genetics, Punjab Agricultural University, Ludhiana-141004 (Punjab), INDIA \\ *Corresponding author. E-mail: husanbrar07@gmail.com
}

Received: December 16, 2016; Revised received: May 20, 2017; Accepted: October 7, 2017

\begin{abstract}
In chickpea, trichomes provide a potential resistance mechanism against Helicoverpa armigera (Hübner). The present study was conducted to evaluate the trichome density and trichome length on leaves and pods on nine genotypes of chickpea. Two types of trichomes were observed, i.e non-glandular (on leaves) and glandular (pods). Few glandular trichomes were observed on leaves and a very few non-glandular trichomes were observed on pods. Highest number of non-glandular trichomes on leaves (33.66 trichomes $\left./ \mathrm{mm}^{2}\right)$ were observed in chickpea genotype 5282. Minimum number of glandular trichomes were observed on pods of genotype GL 25016 (12.66 glandular trichomes per $\mathrm{mm}^{2}$ ). In case of leaves, genotypes ICCL 86111 and GL 25016 recorded maximum non-glandular trichome length of 347.23 and $301.53 \mu \mathrm{m}$, respectively. However, genotypes GL 25016 , RSG 963 and 5282 recorded maximum glandular trichome length of $538.33,564.97$ and $432.61 \mu \mathrm{m}$, respectively in pods. Density of non glandular trichomes on leaves showed significant and negative correlation with number of eggs, larval population, larval survival and per cent pod damage. However, density of glandular trichomes on pods showed significant and positive correlation with number of eggs, larval population of $\mathrm{H}$. armigera, larval survival and pod damage. Length of non-glandular trichomes on leaves and glandular trichomes on pods showed non-significant and negative correlation with number of eggs, larval population of $H$. armigera, larval survival and pod damage. Hence, genotypes with more pubescent leaves, lesser pubescent pods and longer trichomes (both on leaves and pods) should be preferred for developing $H$. armigera tolerant chickpea genotypes.
\end{abstract}

Keywords: Chickpea, Glandular trichomes, Helicoverpa armigera, Non-glandular trichomes

\section{INTRODUCTION}

Chickpea (Cicer arietinum Linn.), also known as Bengal gram is one of the most important pulse crops of India and is considered as "king of pulses". It is a source of high quality protein for the people in many developing countries, including India (Bhatt and Patel 2001). In India, chickpea was grown on $8.25 \mathrm{~m}$ ha area with a production of $7.17 \mathrm{mt}$ (Anonymous, 2015). In Punjab, chickpea was grown in an area of 1.8 thousand ha with a production of 1.9 thousand tonnes with an average yield of 10.85 quintals per hectare during 2016 -17 (Anonymous, 2016). In India, gram pod borer, Helicoverpa armigera (Hübner) is a serious and devastating insect pest of chickpea, affecting both quality and yield (Sharma, 2005). A single $H$. armigera larva is capable of destroying upto 30 pods before it reaches maturity (Ali et al., 2009) and yield losses due to the pest may range from 70 to 95 per cent (Prakash et al., 2007). Insecticides have been widely used for controlling this pest on different crops, but undesirable side effects of synthetic insecticides, including development of resistance, have necessitated a shift to more eco-friendly approaches for controlling this pest (Kranthi et al., 2002). Host plant resistance (HPR) can play a major role in controlling $H$. armigera damage and development of improved chickpea varieties with resistance or tolerance to Helicoverpa is highly useful for minimizing its damage to crop. Several chickpea genotypes with low to moderate levels of resistance have been identified in the past (Sharma et al., 2007). Trichomes and trichome exudates on plant surfaces play an important role in the host selection process of insect herbivores (Bernays and Chapman 1994). Several morphological traits such as leaf and pod trichome length and density, pod wall thickness seem to influence Helicoverpa infestation in chickpea (Ujagir and Khare, 1987). The types of trichomes and their orientation, density and length have been correlated with reduced insect damage in several crops (Peter et al 1995). They could, therefore, provide a potential resistance mechanism against $H$. armigera and other pests of chickpea. Keeping this in view, the present study was conducted to elucidate the role of morphological traits in imparting resistance to $H$. armigera in chickpea.

\section{MATERIALS AND METHODS}

The experiment was conducted at the Electron Microcopy and Nanotechnology Laboratory, Punjab Agricul- 
tural University, Ludhiana, for rabi season 2013. The experiment was conducted at the experimental area of Pulses Section, Department of Plant Breeding and Genetics, Punjab Agricultural University, Ludhiana and nine genotypes of chickpea were grown in open field conditions. Average maximum temperature for the months of November, December, January, February and March was 25.75, 19.75, 17.3, 18.975 and 24.4 C respectively and minimum was 9.725, 7.425, 6.725, 7.6 and $11.6 \mathrm{C}$, respectively and average relative humidity was $64.5,74.5,78,76.5$ and 73.25 per cent, respectively during the year 2013-14. The following nine genotypes of chickpea were screened against $H$. armigera infestation in relation to leaf and pod morphological traits: ICCV 10, ICC 10393, GL 26054, GL 25016, RSG 963, 5282, ICCL 86111 (check), ICC 3137 (check) and L550 (check). The experiment was laid out in a randomized block design with three replications. The seeds of respective genotypes were sown and normal intercultural operations were done.

In order to study the trichomes density and length on pods and leaves of chickpea genotypes, observations were recorded from fully expanded leaves and fullgrown, green pods. The plant material was fixed and imaged under Scanning Electron Microscope (SEM) as per Bozzola and Russell (1999). Fresh leaves of each test genotype were collected and immediately immersed in individual vials containing 2.5 per cent glutaraldehyde solution for primary fixation and kept overnight at a temperature of $4^{\circ} \mathrm{C}$. the leaf specimens were then washed thrice with distilled water. For secondary fixation, the specimens were immersed in 4 per cent osmium tetraoxide solution for a period of 2-4 hours at $4^{\circ} \mathrm{C}$. After post-fixation, the specimens were again washed thrice (each washing of 5 to 10 minute duration) using distilled water. Dehydration of the specimen discs was performed using different grades of ethanol $(25,50,70,95$ and $100 \%)$ each for a period of 20 minutes whereas the final dehydration (with $100 \%$ ethanol) was performed for 30 minutes. The specimens were dried to critical point in $\mathrm{CO}^{2}$ at $5^{\circ} \mathrm{C}$ and mounted on aluminum stub using double-sided carbon tape. Each specimen leaf disc was mounted with its lower surface up allowing the lower epidermal surfaces of each leaf to be examined. The mounted leaf specimens were sputter-coated with a think layer of gold using an automated sputter coater. Finally, the specimens were examined and imaged using Hitachi S$3400 \mathrm{~N}$ Scanning Electron Microscope operated at an accelerating voltage of $15 \mathrm{kV}$ using secondary electron detector. Similar procedure was followed for imaging the samples of pods of test genotypes. Trichome density (both glandular and non-glandular) was calculated by counting the number of trichomes per $\mathrm{mm}^{2}$. Trichome length was also evaluated from the images taken on which length sealing was done using computer software (3 replications).
The significance of differences between the treatments was measured by $\mathrm{F}$ test at $\mathrm{P}=0.05$, whereas the treatment means were compared using the least significant difference (LSD) at $\mathrm{P}=0.05$. The data pertaining to different biophysical traits was analyzed using ANOVA to test for significance among different genotypes. The biophysical traits were subsequently correlated with per cent pod damage, grain yield and larval weight gain using simple linear regression analysis.

\section{RESULTS AND DISCUSSION}

Trichome Density on leaves and pods : The mean trichome density on leaves of chickpea genotypes ranged from 16 to 33.66 trichomes per $\mathrm{mm}^{2}$ and varied significantly (C.D. 5\%) among different genotypes (Table 1). Highest number of trichomes (33.66 trichomes per $1 \mathrm{~mm}^{2}$ ) were observed in chickpea genotype 5282, whereas genotypes ICCL 86111 and RSG 963 were on par with it having trichome density of

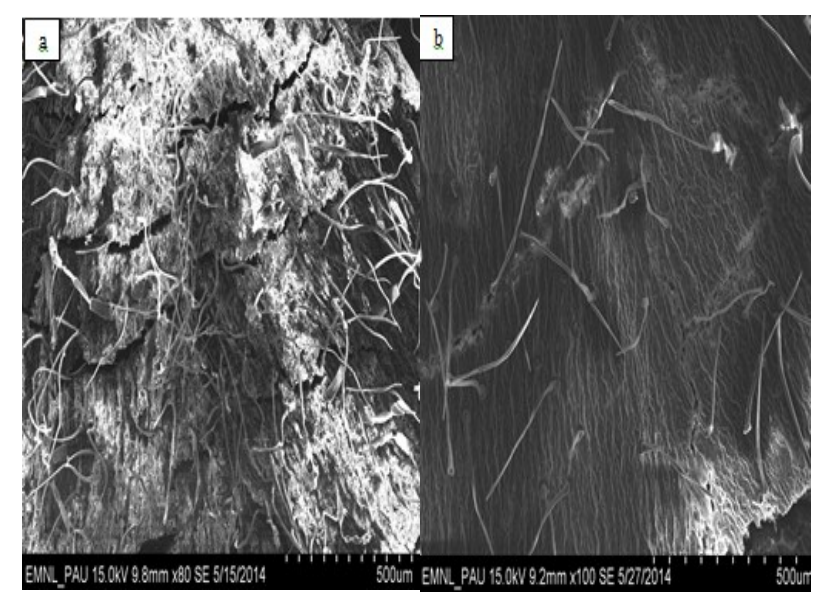

Fig.1. Trichome density(non-glandular) on leaves in chickpea genotypes. (a) Genotype 5282- Resistant (33.66 nonglandular trichomes $/ \mathrm{mm}^{2}$ area) and (b) Genotype ICC 3137 - Highly susceptible (16 non glandular trichomes $/ \mathrm{mm}^{2}$ area).

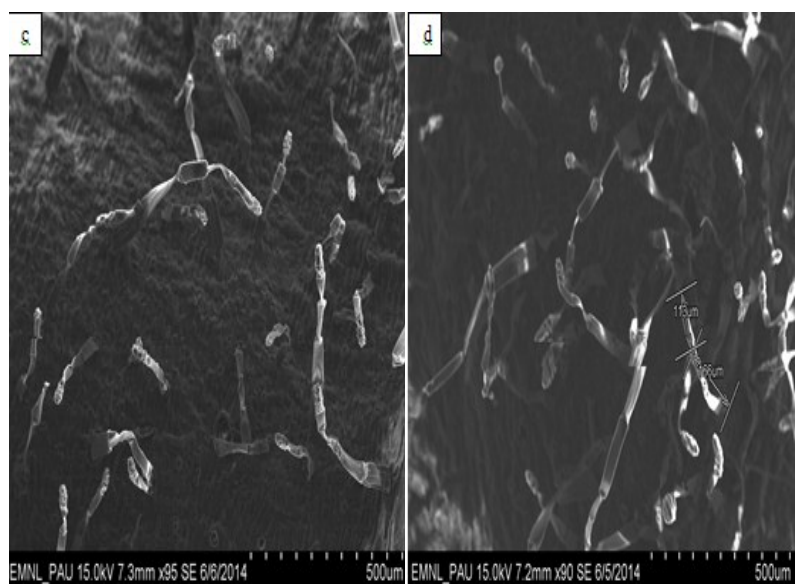

Fig. 2. Trichome density (glandular) on pods in chickpea genotypes (c) Genotype GL 25016 - Resistant (12.66 glandular trichomes $/ \mathrm{mm}^{2}$ area) and (d) Genotype L550 - Susceptible (33.33 glandular trichomes $/ \mathrm{mm}^{2}$ area). 
Husandeep Singh Brar and Ravinder Singh / J. Appl. \& Nat. Sci. 9 (4): 2193 - 2198 (2017)

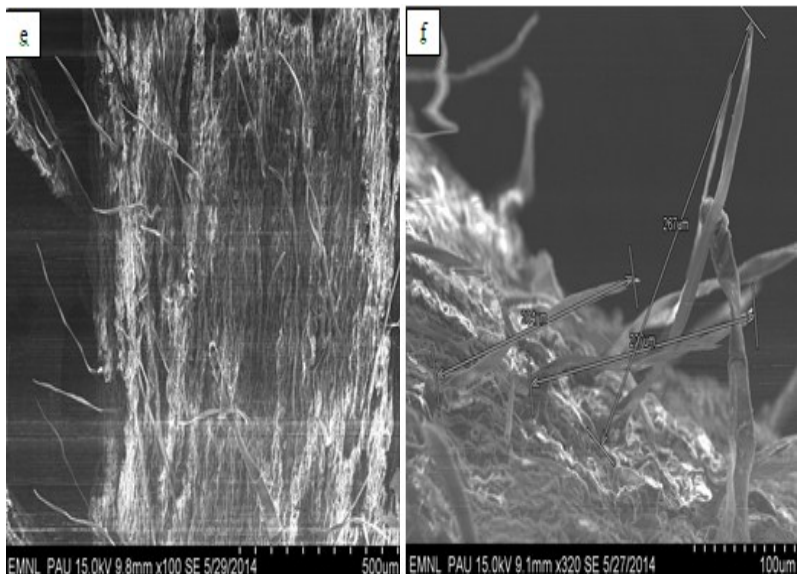

Fig. 3. Trichome length on leaves in chickpea genotypes. (e) Genotype ICCL 86111 - Resistant $(347.23 \mu \mathrm{m})$ and (f) Genotype ICC 10393 - Moderately susceptible (211.86 $\mu \mathrm{m})$.

31.33 and 30.66 trichomes $/ \mathrm{mm}^{2}$ respectively. However, genotypes, GL 25016, ICC 10393, ICCV 10, L550, GL26054 and ICC 3137 recorded significantly lower number of trichomes than resistant chickpea genotype 5282 with density of $23.33,22.33,22.66,20.66,17.66$ and 16.00 trichomes $/ \mathrm{mm}^{2}$ respectively. The variation in non-glandular trichome density on leaves in chickpea genotypes has been depicted in Fig.1.Girija et al (2008) also evaluated the biophysical mechanisms of resistance in 19 genotypes of chickpea for pod borer resistance and found that tolerant genotypes had higher number of trichomes on leaves. Similarly, Sharma and his coworkers (2009) reported that resistance of $\mathrm{Ca}$ janus spp. to Helicoverpa armigera is directly proportional to density of non-glandular trichomes present on the leaves. The number of trichomes on leaves showed a negative significant effect of damage by $H$. armigera (Kanchana et al., 2005). Jagtap et al (2014) at Gujarat reported that genotypes of pigeonpea having nonglandular pod trichomes were least favoured by the larvae of $H$. armigera than genotypes having glandular pod trichomes. Sunita et al (2013) also confirmed that genotypes having more number of trichomes per unit area recorded less pod damage due to Maruca vitrata

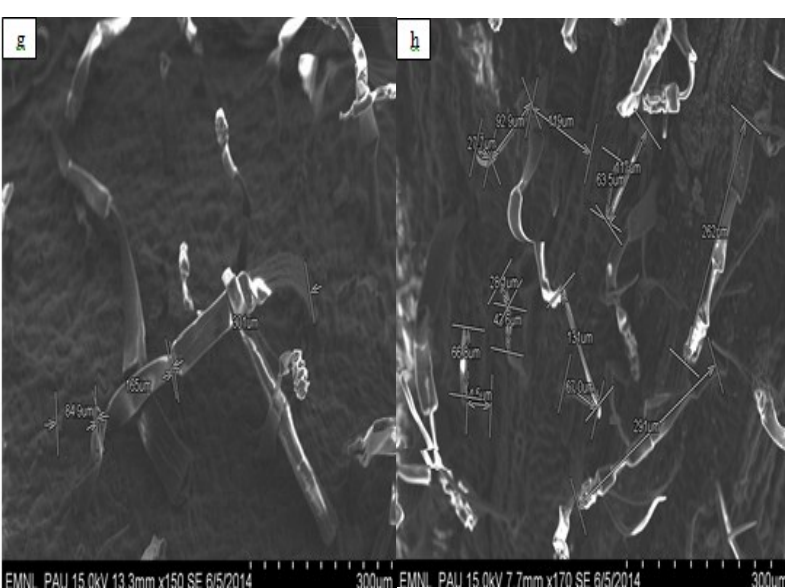

Fig. 4. Trichome length on pods in chickpea genotypes. (g) Genotype RSG 963 - Resistant (564.97 $\mu \mathrm{m})$ and (h) Genotype L 550 - Highly susceptible $(292.87 \mu \mathrm{m})$.

in pigeonpea and a non-significant negative correlation was observed between trichome density and pod damage due to $M$. vitrata $(\mathrm{r}=-0.209)$. Johnpeter et al (1995) investigated that the tolerant genotypes viz., ICCL 87315, ICC 506 and ICC 12479 with higher number of trichomes exhibited less percent pod damage, while susceptible genotypes viz., Annigeri and ICCV 2 with lesser number of trichomes showed higher pod damage. Ascensao and his co-workers in 1995 reported that higher densities of non glandular trichomes may also act as a physical barrier to feeding by H.armigera larvae.

In case of pods, the density of glandular trichomes was taken into consideration. The mean trichome density varied significantly among different genotypes (C.D. $5 \%$ ). Density of glandular trichomes on pods ranged from 12.66 to 33.33 trichomes $/ \mathrm{mm}^{2}$. Minimum number of glandular trichomes on pods were observed in genotype GL 25016 (12.66 glandular trichomes per $\mathrm{mm}^{2}$ ) which was on par with genotype ICC 10393 (18 glandular trichomes per $\mathrm{mm}^{2}$ ). Genotypes, GL 26054, RSG 963, 5282 and ICCL 86111 recorded significantly higher trichome densities of 24.67, 21.66, 24.33 and 22 glandular trichomes per $\mathrm{mm}^{2}$, respectively as shown in

Table 1. Trichome density and average pod wall thickness on different genotypes of chickpea during $2013-14$.

\begin{tabular}{|c|c|c|c|c|c|}
\hline \multirow[t]{2}{*}{ Genotype } & \multicolumn{2}{|c|}{$\begin{array}{c}\text { Trichome density on leaves } \\
\left(\text { per } \mathrm{mm}^{2}\right)^{*}\end{array}$} & \multicolumn{2}{|c|}{$\begin{array}{c}\text { Trichome density on pods } \\
\left(\text { per } \mathbf{m m}^{2}\right)^{*}\end{array}$} & \multirow[t]{2}{*}{$\begin{array}{l}\text { Average pod wall } \\
\text { thickness (mm)* }\end{array}$} \\
\hline & Non glandular & Glandular & Non glandular & Glandular & \\
\hline ICCV 10 & $22.66(4.86)$ & $6.33(2.70)$ & $2.33(1.79)$ & $27.33(5.32)$ & 0.293 \\
\hline ICC 10393 & $22.33(4.82)$ & $5.66(2.58)$ & $2.00(1.62)$ & $18.00(4.33)$ & 0.273 \\
\hline GL 26054 & $17.66(4.31)$ & $3.00(1.98)$ & $3.00(1.98)$ & $24.67(5.06)$ & 0.290 \\
\hline GL 25016 & $23.33(4.89)$ & $5.33(2.50)$ & $0.33(1.14)$ & $12.66(3.64)$ & 0.283 \\
\hline RSG 963 & $30.66(5.62)$ & $6.33(2.68)$ & $2.00(1.73)$ & $21.66(4.75)$ & 0.300 \\
\hline 5282 & 33.66 (5.83) & $6.67(2.76)$ & $1.33(1.52)$ & $24.33(5.01)$ & 0.316 \\
\hline ICCL 86111 & $31.33(5.68)$ & $5.00(2.43)$ & $0.00(1.00)$ & $22.00(4.79)$ & 0.270 \\
\hline ICC 3137 & $16.00(4.12)$ & $3.66(2.15)$ & $2.67(1.91)$ & $27.67(5.35)$ & 0.313 \\
\hline L550 & $20.66(4.62)$ & $6.67(2.76)$ & $4.67(2.37)$ & $33.33(5.85)$ & 0.296 \\
\hline C.D. $5 \%$ & $(0.84)$ & $(0.47)$ & $(0.56)$ & $(0.70)$ & NS \\
\hline
\end{tabular}

Figures in parentheses are the transformed $\sqrt{ } n+1$ values, $*$ Mean of three replications 
Table 2. Trichome length of leaves and pods of different genotypes of chickpea during 2013 - 14 .

\begin{tabular}{lcccc}
\hline \multirow{2}{*}{ Genotype } & \multicolumn{2}{c}{ Trichome length on leaves $(\boldsymbol{\mu m})^{*}$} & \multicolumn{2}{c}{ Trichome length on pods $(\boldsymbol{\mu m})^{*}$} \\
\cline { 2 - 5 } & Non glandular & Glandular & Non glandular & Glandular \\
\hline ICCV 10 & $237.86(15.39)$ & $229.76(15.11)$ & $273.00(16.53)$ & $349.94(18.72)$ \\
ICC 10393 & $211.86(14.45)$ & $220.26(14.87)$ & $320.67(17.92)$ & $367.67(19.16)$ \\
GL 26054 & $239.58(15.50)$ & $244.88(15.67)$ & $218.00(14.78)$ & $353.33(18.80)$ \\
GL 25016 & $301.53(17.36)$ & $294.93(17.19)$ & $232.67(15.28)$ & $538.33(23.20)$ \\
RSG 963 & $285.00(16.90)$ & $297.98(17.28)$ & $409.83(20.20)$ & $564.97(23.78)$ \\
5282 & $259.67(16.13)$ & $254.66(15.98)$ & $211.67(14.56)$ & $432.61(20.80)$ \\
ICCL 86111 & $347.23(18.66)$ & $348.25(18.68)$ & $0.00(1.00)$ & $491.67(22.10)$ \\
ICC 3137 & $220.75(14.84)$ & $258.75(16.09)$ & $200.67(14.19)$ & $328.63(18.13)$ \\
L550 & $232.04(15.26)$ & $225.06(15.03)$ & $177.33(13.34)$ & $292.87(17.11)$ \\
CD $(\mathrm{p}=0.05)$ & $(2.15)$ & $(1.28)$ & $(1.57)$ & $(2.27)$ \\
\hline
\end{tabular}

Figures in parentheses are the transformed $\sqrt{ } n+1$ values, * Mean of three replications

Table 3. Correlation between morphological characteristics of leaves and pods of different genotypes of chickpea and population of H. armigera during $2013-14$.

\begin{tabular}{lcccc}
\hline Characters & \multicolumn{4}{c}{ Correlation coefficient (r) } \\
\cline { 2 - 5 } & Eggs & $\begin{array}{c}\text { Per cent } \\
\text { larval survival }\end{array}$ & $\begin{array}{c}\text { Larval } \\
\text { Population }\end{array}$ & $\begin{array}{c}\text { Per cent pod } \\
\text { damage }\end{array}$ \\
\hline $\begin{array}{l}\text { Trichome density } \\
\text { (Non glandular) on leaves }\end{array}$ & $-0.76^{*}$ & $-0.78^{*}$ & $-0.77^{*}$ & $-0.67^{*}$ \\
$\begin{array}{l}\text { Trichome density } \\
\text { (Glandular) on pods }\end{array}$ & $0.75^{*}$ & $0.76^{*}$ & $0.74^{*}$ & $0.69^{*}$ \\
$\begin{array}{l}\text { Trichome length } \\
\text { (Non glandular) on leaves }\end{array}$ & -0.62 & -0.62 & -0.61 & -0.50 \\
$\begin{array}{l}\text { Trichome length } \\
\text { (Glandular) on pods }\end{array}$ & -0.56 & -0.55 & -0.58 & -0.58 \\
Pod wall thickness (mm) & $\mathrm{NS}$ & $\mathrm{NS}$ & $\mathrm{NS}$ & $\mathrm{NS}$ \\
\hline
\end{tabular}

* Significant at $5 \%$ level of significance

Table 1 (At $5 \%$ level of significance). Genotypes ICCV 10 and ICC 3137 were on par with each other with trichome densities of 27.33 and 27.67 glandular trichomes per $\mathrm{mm}^{2}$, respectively. The variation in glandular trichome density on pods in chickpea genotypes has been depicted in Fig.2. Variation in larval survival of H.armigera in relation to trichome density on leaves of chickpea genotypes has been depicted in fig.5. Per cent pod damage in relation to trichome density on pods of chickpea genotypes has been depicted in fig. 6. The present findings are in contrast with the work done by Hossain et al (2008) who observed that pod trichome density had negative correlation $(\mathrm{y}=-14.274 \mathrm{x}+25.861 ; \mathrm{R} 2=0.175)$ to pod borer damage in chickpea. Also, Shanower and his coworkers in 1997 found that trichomes on pods of $\mathrm{Ca}$ janus spp. to be an important resistance mechanism against $H$. armigera and suggested that increasing the density of non-glandular trichomes in pigeonpea pods could reduce damage and losses due to pod feeding insect pests. Green et al (2003) reported that high density of glandular trichomes increases the vulnerability of host plant to H.armigera to feed on the pod because of the reason that the exudates from these trichomes contain a feeding stimulant for larvae. Shabbir et al (2014) reported genotypes which had higher pod trichome density and pod wall thickness were more resistant. Sharma et al. (2009) at Andhra Pradesh also reported that glandular trichomes (type A) on the calyxes and pods were associated with the susceptibility to $H$. armigera, while the non-glandular trichomes were associated with resistance to this insect. Veeranna and Hussain (1997) observed that with increased density of non-glandular trichomes on pods, the damage due to pod feeding insects was reduced in pigeon pea. Peter (1995) also confirmed that pigeonpea non-glandular trichomes are one of the critical factors for the pod borer antibiosis and antixenosis mechanisms. Katti and Bhatia (1993) observed the influence of pod characters on pod damage by $H$ armigera.

Trichome length on leaves and pods: Length of only non-glandular trichomes were considered in case of leaves. The length of non-glandular trichomes ranged from 211.86 to $347.23 \mathrm{~mm}$ on leaves (Table 2). Minimum trichome length was found in genotype ICC $10393(211.86 \mathrm{~mm})$ and genotypes ICCV 10, GL 26054, 5282, ICC 3137 and L 550 were on par with it having trichome length of 237.83, 239.58, 259.67, 220.75 and $232.04 \mathrm{~mm}$, respectively. Genotype ICCL 86111, GL 25016 and RSG 963 comparatively length trichome length of $347.23,301.53$ ad $285.00 \mathrm{~mm}$, respectively.

In case of pods, length of glandular trichomes were considered. The mean trichome length on pods varied significantly among different genotypes. The mean length of glandular trichomes on pods ranged from 


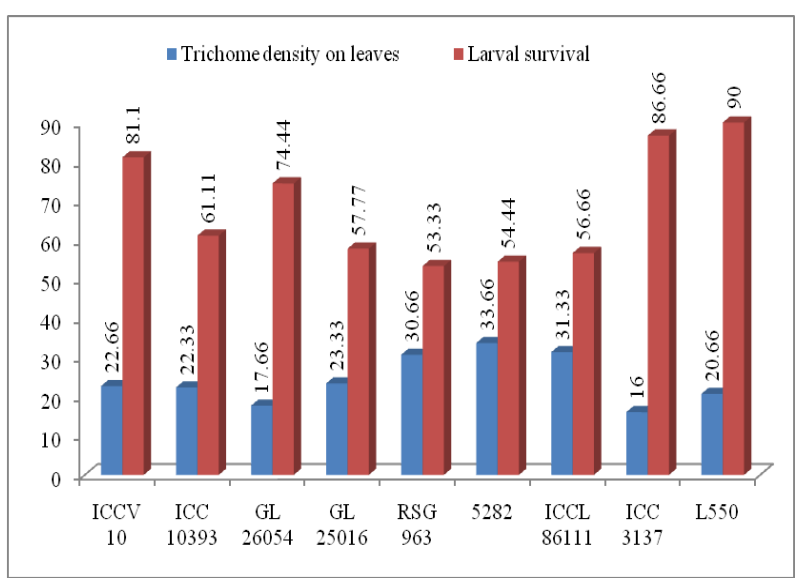

Fig. 5. Larval survival of H.armigera in relation to trichome density on leaves of chickpea genotypes.

292.87 to $564.97 \mathrm{~mm}$. Shortest length glandular trichome in genotype L $550(292.87 \mathrm{~mm})$ and remaining genotypes ICCV 10, ICC 10393, GL 26054 and ICC 3137 were on par with it having trichome length of $349.94,367.67,353.33$ and $328.63 \mathrm{~mm}$, respectively. Genotype GL 25016, RSG 963, 5282 and ICCL 86111 comparatively longer trichome length of 538.33, $564.97,432.61$ and $491.67 \mathrm{~mm}$, respectively. The variation in glandular and non-glandular trichome length on leaves and pods of different chickpea genotypes is depicted in Figure 3 and 4, respectively.Kalyani et al (2017) confirmed that trichome length was significant and negatively correlated $(\mathrm{r}=0.833)$ with pod infestation. Shabbir et al (2014) also reported that genotypes with higher trichome length, are more resistant. These results are in agreement with the studies of Hossain et al (2008) who observed that the chickpea pods having longer trichomes received lower pod borer damage. Peter et al (1995) reported that the length of pod trichomes in pigeonpea provided potential host plant resistance mechanism to H. armigera. Pods with longer trichomes might provide physical barrier to feeding by pod borer.

Trichome density of non glandular trichomes on leaves showed significant and negative correlation with number of eggs, larval population, larval survival and per cent pod damage ( $\mathrm{r}=-0.76,-0.77^{*},-0.78^{*}$ and $-0.67^{*}$, respectively) indicating that more the trichome density or leaf pubescence, lesser would be the number of $H$. armigera eggs, larval population, larval survival and pod damage (Table 3). Thus, pubescent chickpea genotypes were less preferred for feeding and oviposition by $H$. armigera as compared to glabrous ones. However, trichome density of glandular trichomes on pods showed significant and positive correlation with number of eggs and larval population of $H$. armigera, larval survival and pod damage $(\mathrm{r}=0.75,0.75,0.76$ and 0.69 , respectively) indicating that more the glandular trichome density on pods, more would be the number of $H$. armigera eggs, larval population, larval survival

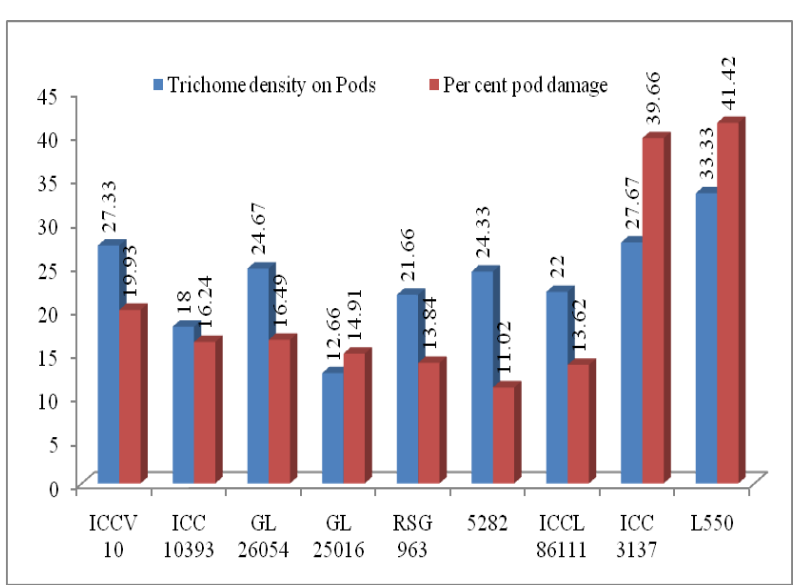

Fig. 6. Per cent pod damage in relation to trichome density on pods of chickpea genotypes.

and per cent pod damage. Thus less pubescent chickpea genotypes were less preferred for feeding and oviposition by $H$. armigera as compared to glabrous ones. Trichome length of non-glandular trichomes on leaves and glandular trichomes on pods showed nonsignificant and negative correlation with number of eggs, larval population of $H$. armigera, larval survival and pod damage $(\mathrm{r}=-0.62,-0.61,-0.62$ and -0.50 , respectively) indicating that more the non-glandular and glandular trichome length on leaves and pods respectively, lesser would be the number of $H$. armigera eggs, larval population, larval survival and per cent pod damage.

\section{Conclusion}

Results on varietal ranking of chickpea genotypes showed that all the genotypes showed variable response. The chickpea genotypes 5282, ICCL 86111, GL 25016, RSG 963 and ICC 10393 exhibited less oviposition $(5.28,5.60,5.75,5.61$ and 6.30 eggs per five plants, respectively) lesser larval survival (3.56, $3.91,3.94,3.88$ and 4.41 larvae per five plants, respectively), lesser Pest Resistance Susceptible Rating (PRSR) values of 3 , less per cent pod damage (11.02, $13.62,14.91,13.84$ and 16.24 , respectively) and higher grain yield $(9.56,9.93,13.88,12.96$ and $9.56 \mathrm{q} / \mathrm{ha}$, respectively). Larval weight gain $(1.01,0.16,1.85$, 1.88 and $0.19 \mathrm{~g}$, respectively) and pupal weight gain $(0.16,0.16,0.16,0.17$ and $0.17 \mathrm{~g}$, respectively) were also found less in these genotypes. The combined action of different traits might be operating in these genotypes. Hence, genotypes with more pubescent leaves, lesser pubescent pods and longer trichomes (both on leaves and pods) should be preferred. These genotypes can be used as resistant sources in breeding programmes to enhance resistance / tolerance to pod borer in commercial cultivars.

\section{REFERENCES}

Ali, A, Choudhury, R.A, Ahmad, F.R, Khan, F.R. and Ah- 
mad, S.K. (2009). Some biological characteristics of Helicoverpa armigera on chickpea. Tunisian Journal of Plant Protection, 4: 99-106.

Anonymous (2015) Project Co-ordinator's Report, All India Coordinated Research Project on Chickpea. Indian Institute of Pulses Research, Kanpur 44 pp.

Anonymous (2016) Package of Practices for Rabi Crops of Punjab. Pp 29-33. Punjab Agricultural University, Ludhiana.

Ascensao L, Marques N, Pais M S (1995) Glandular trichomes on vegetative and reproductive organs of $\mathrm{Le}$ onotis leonurus (La-Maiacez). Ann Bot (London) 75: 619-26.

Bernays, E.A. and R.F. Chapman. (1994) Host-plant Selection by Phytophagous Insects. Chapman and Hall, New York.

Bhatt, N.J. and Patel, R.K. (2001). Screening of chickpea cultivars for their resistance to gram pod borer. Helicoverpa armigera. Indian Journal of Entomology, 63: 277-280.

Bozzola, J.J. and Russell, L.d. (1999). Electron Microscopy : Principles and techniques for biologists. $2^{\text {nd }}$ Edition, Jones and Bartlett Publishers, Inc. Sudbury, MA, USA, Pp. 670.

Girija, Salimath, P.M., Patil, S.A., Gowda, C.L.L. and Sharma, H.C. (2008) Biophysical and biochemical basis of host plant resistance to pod borer (Helicoverpa armigera Hubner) in chickpea (Cicer arietinum L.). Indian Journal of Genetics, 68: 320-23.

Green, P. W. C., Stevenson, P. C., Simmonds, M. S. J and Sharma H C (2003) phenolic compounds of the pod surface of pigeonpea, Cajanus cajan, mediate feeding behavior of Helicoverpa armigera larvae. J Chem Ecol 29:811-21

Hossain, A, Haque, A and Prodhan, M.Z.H. (2008). Effect of pods characteristics on pod borer, Helicoverpa armige$r a$ (Hubner), investigation in chickpea. SAARC Journal of Agriculture, 6.

Jagtap, W R, Achaiva, S, Patel, 3. W and Lal, B. (2014). Impact of Morphological and chemical constitution of genotypes on incidence of Helicoverpa in pigeonpea [Cajanus Cajan (L.) Millsp] Journal of Food Legumes. 27(1) 48-51.

Johnpeter A, Shanower T G and Romes J (1995) The role of plant trichomes in insect resistance: a selective review. Phytophaga 7: 41-64.

Kalyani, Y., and Chavan, A. P., and Holay., P.U., and Patil, S. K. (2017) Correlation of biophysical attributes on Helicoverpa armigera infestation in Chick pea. Annalsof Plant Protection Sciences 25 (1) : 215-230.

Kanchana R, Lakshmi K V and Sekhar P R (2005) Morphological and biochemical bases of host plant resistance to Helicoverpa armigera (Hubner) in chickpea. J Plant
Prot Environ 2: 12-17.

Katti G and Bhatia V S (1993) Preliminary studies on the influence of pod characters on pod damage in chickpea. Indian J Pulses Res 6: 215-16.

Kranthi, K.R., Jadhav, D.R., Kranthi, S., Wanjari, R.R., Ali, S.S. and Russel, D.A. (2002) Insecticide resistance in five major insect pests of cotton in India. Crop Protection 21: 449-460.

Peter A J (1995). Pigeonpea trichomes: a promising source for pod borer resistance. IPM and IRM Newsletter for Legume Crops in Asia, 2: 5-6.

Prakash, M.R., Ram, U. and Tariq, A. (2007). Evaluation of chickpea (Cicer arietinum L.) germplasm for the resistance to gram pod borer, Helicoverpa armigera Hubner (Lepidoptera: Noctuidae). Journal of Entomological Research, 31: 215-218.

Shabbir, M.Z., M. Arshad, B. Hussain, I. Nadeem, S. Ali, A. Abbasi and Q. Ali (2014). Genotypic response of chick pea (Cicer arietinum L.) for resistance against Helicoverpa armigera. Journal of Biological. Sciences. 2: 23 -30 .

Shanower, T.G., Yoshida, M. and Peter, A.J. (1997) Survival, growth, fecundity and behaviour of Helicoverpa armigera (Lepidoptera: Noctuidae) on pigeonpea and two wild Cajanus species. Journal of Economic Entomology, 90: 837-41.

Sharma, H. C, Sujana, G. and Monohar D (2009) Morphological and chemical components of resistance to pod borer,Helicoverpa armigera in wild relatives of pigeonpea.Arthropod plant interactions 3: 151-61

Sharma, H.C. (2005). Heliothis / Helicoverpa Management : Emerging Trends and Strategies for Future Research. Oxford \& IBH Publishing Co. Pvt. Ltd., New Delhi, India.

Sharma, H.C., Gowda, C.L.L., Stevenson, P.C., RidsdillSmith, T.J., Clement, S.L., Ranga Rao, G.V., Romeis, J., Miles, M., El Boushssini, M. (2007). Host plant resistance and insect pest management in chickpea. In: Yadav, S.S., Redden, R.J., Chen, W., Sharma, B. (Eds.), Chickpea Breeding and Management. CABI Pub.

Sunita, D. M., Sreekanth, M. and Raniachandar, R. M. (2013). Influence of morphological traits on spotted pod borer, Maruca vitrata resistance in pigeonpea. Indian Journal of Plant Protection 41(1): 97-99.

Ujagir R., and Khare B.P., (1987) Preliminary screening of chickpea genotypes for suceptability to Heliothis armigera (Hubner) at Pantnagar, India, International Chickpea Newsletter 17:14.

Veeranna ,R and Hussain, M. A. (1997) Trichomes as physical barriers for cowpea pod borer Maruca testulalis (Geyer) (Lepidoptera: Pyralidae). Insect Environment 3: 15 . 